\title{
A PRESENÇA DE MICHEL FOUCAULT NOS ANARQUISMOS
}

\section{The presence of Michel Foucault in the anarchisms}

\author{
Edson Passetti*
}

\begin{abstract}
RESUMO
$\mathrm{O}$ artigo situa a presença de Michel Foucault nos anarquismos a partir da genealogia do poder e estabelece distinções entre o ativismo e o militantismo.

Palavras-chave: anarquismos; Foucault; militantismo; ativismo
\end{abstract}

\begin{abstract}
The article situates the presence of Michel Foucault in anarchisms from the genealogy of power and distinguishes between activism and militantism.
\end{abstract}

Keywords: anarchisms; Foucault; militantism; activism

As provocativas colocações de Michel Foucault a respeito do anarquismo são alvos de comentários regulares por pesquisadores atentos e por anarquistas surpresos. Estabelecer uma escala de relevância quanto a isso ser bom ou ruim para os anarquismos é uma investida pouco relevante neste momento. Recairia numa disputa pelo justo, em uma discussão acerca da superioridade de saber, sobre o ideal ascético e até mesmo o ressentimento (Nietzsche, 1998).

Como é sabido, Nietzsche dedicou algumas reflexões acerca do anarquismo entre seus escritos, geralmente de modo depreciativo,

* Professor livre-docente no Departamento de Política e Programa de Estudos Pósgraduados em Ciências Sociais e coordenador do Nu-Sol (Núcleo de Sociabilidade Libertária) PUCSP. www.nu-sol.org.

E-mail: passetti@matrix.com.br 
mas em algumas ocasiões destacou alguns diferenciais. Talvez, o que chama mais a atenção, em relação aos propósitos deste estudo, seja aquele relativo às implicações acerca da emergência do bom, bem, ruim, mal que é próprio de homens superiores (aristocratas) e que dentre esses corajosos e guerreiros também fez aparecer os sacerdotes que estabeleceram a distinção entre o puro-impuro e que compõem os proprietários da língua, a procedência das religiões e da filosofia. Projetada para o socialismo e para as lutas pela liberdade nos séculos XIX e seguintes, a decadência aristocrática passou por uma transição que culminou na metamorfose da aristocracia em elites da ordem e vanguardas revolucionárias. Se o possível ressentimento anarquista se funda num justo exclusivo com pretensões universais, situando os inimigos como maus, colocando-se, segundo Nietzsche, aninhados aos ressentidos, a aversão à condução pelo alto diferencia os anarquistas e produz a centelha diferencial das práticas anarquistas. Todavia, entre os anarquistas que pretendem disputar uma hegemonia interna e os demais está a recusa à condução bloqueadora de mortificações religiosas, mas como evitar o templo religioso anarquista de proveniência iluminista? Neste ponto, encontra-se uma possível reversão por similitude da definição do bom, ruim, errado, etc., muito constante entre os ressentidos, segundo Nietzsche, e que configura um antiposicionamento direto aos democratas com suas elites, e aos revolucionários da vanguarda que pretendem tomar $\mathrm{o}$ poder.

As práticas anarquistas se voltam para a implosão dos condutores de consciência e essa é a sua grandiosidade corajosa e heroica diante dos demais socialistas, comunistas e democratas. Os anarquistas são certeiros na crítica intransigente aos reformistas e revolucionários profissionais desde o século XIX e a militância governada. São também certeiros, desde Proudhon, nas análises acerca da transição da série autoridade para a série liberdade, e que também aparece em Nietzsche ${ }^{1}$, ao situar a revolta como o que nos

1 “A imprecisa observação geral enxerga em toda natureza oposições ('quente e frio', por exemplo), onde não há oposições, mas apenas diferenças de grau. Esse mau hábito nos induziu a querer entender e decompor segundo estas oposições também a natureza interior, o mundo ético-espiritual. Não há ideia de quanta dor, presunção, dureza, alienação e frieza foi incorporada à sensibilidade humana, ao se acreditar ver oposições, em vez de transições" (Nietzsche, 2008, [67], p. 201). 
diferencia dos animais, como colocou Bakunin (2001), ou ainda com o rompimento da relação egoísta/não-egoísta sistematizada por Max Stirner (2004), um anarquista no anarquismo, no final dos anos 1840. Tudo isso antes de Nietzsche e de suas incontornáveis críticas. Os anarquistas reviraram pelo avesso a continuidade da condução pelos superiores de herança aristocrática, e neste sentido, dão mais que um passo em direção a estancar o eterno retorno do mesmo. Estes breves lembretes estão no instante propício para situar os anarquismos como uma reversão e não somente mais uma prática do ressentimento.

Trazer Nietzsche para a abertura desta reflexão está diretamente relacionado a Foucault e as suas variadas relações com os anarquismos e que não são poucas, assim como uma necessária revisão crítica acerca da militância. Estas relações vão das muito conhecidas considerações acerca da supressão do sujeito como em $A$ hermenêtica do sujeito (2004); sobre um quê de anarquismo em sua metodologia em Do governo dos vivos; em sua atenção ao final de Vigiar e punir (1977) contra o direito penal, o chamado crime e os assujeitamentos, enfim, já foram amplamente situadas e são capazes de continuar encontrando consensos, polêmicas e a produzir retóricas. Mas, intensamente, elas produzem atitudes parresiásticas, que são próprias das práticas anarquistas.

Minha observação neste artigo não buscará o famoso artigo de Foucault sobre a genealogia, conhecido entre nós desde a publicação da seleta de escritos chamada de Microfísica do poder, também texto referência para foucaultianos e anarquistas, para o bom e o mau. E, em consonância com a observação acima de Nietzsche em Genealogia da moral (1998) e do aforisma sobre a transição em Humano demasiado humano - O andarilho (2008) me aterei, inicialmente, às considerações da conferência I em $A$ verdade e as formas jurídicas (1996) e a um comentário de Foucault com o público transcrito ao final destas alocuções, em 1973, na PUC-RJ.

Procurarei, ao final, situar a atualidade da noção de militantismo a partir de $A$ coragem da verdade (2011) relacionada às práticas de liberdade na atualidade e estabelecer, nestes tempos de racionalidade neoliberal, algumas pistas sobre o ativismo político a partir da arte de Ai Weiwei. As práticas de liberdade tão ao gosto da racionalidade neoliberal não devem se confundir com práticas anarquistas, mas produzem uma neblina entre nós. Seria um sinal para 
uma breve retirada anarquista da convocação à participação tão em voga? Seria um instante perspicaz de soterrar a distinção individualismo-coletivismo nos anarquismos compreendendo-a não como oposição binária, determinação de um pelo outro, mas somente uma transição? Seria deixar o presente livre de quaisquer conduções para que as práticas libertárias ganhem maior impulso?

\section{Convalescência}

Entre os anarquistas as proximidades com Foucault foram situadas por Daniel Colson, Margareth Rago, Salvo Vaccaro, Saul Newman, Silvio Gallo Thomaz Ibañez e tantos outros, estabelecendo interessantes conversações com os pensadores históricos do anarquismo e as práticas históricas e recentes. A estes, somaram-se outros ao situarem as sugestões de Foucault relacionando-as às práticas anarquistas na contemporaneidade como Acácio Augusto, Camila Jourdan, João da Mata... E, obviamente, as análises acerca das positividades do poder, do direito e da prisão fomentaram um pouco o abolicionismo penal direta ou indiretamente relacionado com as práticas libertárias, como constatam os trabalhos de Salete Oliveira ${ }^{2}$. As incursões pela genealogia do poder e, às vezes, combinadas com as implicações derivadas da estética da existência absorveram Foucault em estudos universitários, principalmente acerca das disciplinas e prisões e abriram portas para os alpinistas acadêmicos. Mas nenhum destes dois trajetos serão mote deste artigo. $\mathrm{O}$ interesse neste momento recai nas sugestões de Michel Foucault acerca do militantismo e das práticas de liberdade e não acerca de polêmicas. Por isso mesmo, não abordarei o estigma atribuído a Foucault como nocivo ao anarquismo, bastante disseminada entre alguns anarquistas no Brasil. Muito menos se Foucault é mais interessante que Deleuze,

2 As referências aos escritos destes pesquisadores são muitas e estão em grande parte disponibilizados em revistas eletrônicas e sites na internet. 
ou vice-versa, para a análise das práticas contemporâneas de crítica à democracia e as suas deformações tomadas de forma recorrente na mídia jornalística como populismo, ou mesmo nas condições que a democracia representativa e participativa encontra para dar passagem às mais variadas formas de fascismos. Estou interessado em registrar apenas que a presença de Michel Foucault não passa em branco entre os anarquistas e que há certa saúde nesta incursão. Minimamente coerente com os propósitos deste artigo, pretendo situar as práticas de liberdade neoliberais com seu correspondente ativismo em função de uma inevitável governamentalidade planetária que atravessamos, a qual não só borra as consolidações da militância revolucionária como a inclui entre os ativismos, principalmente desde a hegemonia reformista na chamada esquerda. E isto, obviamente, repercute nas práticas libertárias, enfrentando variados cerceamentos à sua disseminação e mesmo existência, e em menor grau suas disposições para o diálogo democrático. Nos termos de Foucault o militantismo é uma revolta à institucionalização da militância e nele há certa construção da vida como obra de arte. Neste sentido, as práticas anarquistas estão em um acontecimento cínico, trans-histórico e descontínuo que ultrapassa a reversão da estética aristotélica levada a cabo pelos artistas da arte moderna e situam as dissoluções de arte levadas adiante desde Marcel Duchamp, um leitor assíduo de Max Stirner. Todavia, a captura de Duchamp pelo ativismo artístico performático desde o final do século passado, vinculado a uma renovação do liberalismo nas artes, levou-me a encontrar no artista militante Weiwei uma expressão contundente desta realização concomitante à glorificação da democracia. Levou-me, também, para a tensa relação entre ativismo-militância-militantismo na qual as práticas anarquistas sobressaem como obra de arte, dissolvendo a expressão do ressentimento e o reposicionamento da arte dos superiores como no ativismo. As considerações serão incompletas, mas situarão a emergência desta singularidade. 


\section{Contra saidas e entradas fáceis}

Perguntado sobre a arqueologia, Foucault respondeu: "o que procuro fazer não é algo que esteja ligado à arte, mas sim uma espécie de atividade. Uma espécie de atividade, mas não uma disciplina" (Foucault, 1996, p. 155). Momentos antes, ainda no debate com intelectuais na PUC-RJ, ele sublinhara algo presente em suas atenções para com o anarquismo:

Não aprovo a análise simplista que consideraria o poder como uma coisa só. Alguém disse aqui que os revolucionários procuram tomar o poder. Aí, eu seria muito mais anarquista. É preciso dizer que não sou anarquista no sentido em que não admito essa concepção inteiramente negativa do poder, mas não concordo com vocês quando dizem que os revolucionários pretendem tomar o poder. (...) Para os autênticos revolucionários, apoderar-se do poder significa apoderar-se de um tesouro nas mãos de uma classe e entregá-lo a uma outra classe, no caso o proletariado. Creio que é assim que se concebe a revolução e a tomada do poder. Então observem a União Soviética. Temos um regime onde as relações de poder na família, na sexualidade, nas fábricas, nas escolas, são as mesmas. O problema é saber se podemos, dentro do regime atual, transformar em níveis microscópicos — na escola, na família - as relações de poder de tal maneira que, quando houver uma revolução político-econômica, não encontremos, depois, as mesmas relações de poder que encontramos agora (Idem, pp. 154-155).

Foucault está interessado em desmontar a construção do sujeito para encontrá-lo no interior da história, na qual ele é fundado e refundado por ela, em novas formas de subjetividades. Filiada a Nietzsche, a análise do discurso diz respeito à "análise histórica do nascimento de um certo tipo de saber, sem nunca admitir a preexistência de um sujeito de conhecimento" (Idem, p. 13). Está no âmbito das lutas, dos baixos começos, de uma invenção que se opõe à 
origem, cujo conhecimento nada mais é que resultante de afrontamentos, efeito dos instintos, centelha entre duas espadas de ferros diferentes. Não há origem e evolução, somente uma continuidade natural.

Entre conhecimento e instintos há rupturas, relações de domínio e subalternidade, relações de poder; não há mais Deus, não há sujeito, mas sujeitos. Para compreender as coisas, distanciando-se de Spinoza e aproximando-se de Nietzsche, intelligere não se opõe a ridere, pois ridere (rir), lugere (deplorar) e detestari (detestar) compõem um resultado que é o intelligere. São as más relações e a recusa ao adestramento dos instintos, o afastamento de Platão e do conhecimento como logocentrismo que se funda na semelhança, adequação, beatitude e unidade. Com Nietzsche, Foucault busca o conhecimento no ódio, na luta, na relação de poder; conhecimento prospectivo, conhecimento como relação estratégica em que o humano está situado ${ }^{3}$. Portanto, o conhecimento é parcial, oblíquo, perspectivo; é da ordem do duelo. Entramos "em uma história política do conhecimento, dos fatos do conhecimento e do sujeito do conhecimento" (Idem, 23). O conhecimento "é um efeito ou um acontecimento que pode ser colocado no signo do conhecer. $\mathrm{O}$ conhecimento não é uma faculdade, nem uma estrutura universal" (Idem, p. 24).

Foucault não é anarquista quando estes se voltam às negatividades do poder, mas o é quando intercepta os revolucionários militantes voltados à tomada do poder e à continuidade de relações de poder que deveriam estar suprimidas quando do evento revolucionário no acontecimento liberdade. Foucault é bastante rigoroso quanto à universalidade pretendida pelos anarquistas, mas nem tanto quanto às práticas anarquistas como heterotopias.

Quando Proudhon sinalizou, a partir de suas análises sobre as forças em luta diante da suposta supremacia da Ideia, que as práticas anarquistas inventam uma vida outra no "mundo" em que vivemos, havia aí uma invenção militantista nas práticas que promoviam a transição da série autoridade para a série liberdade, considerando não

3 Nietzsche ao comentar a punição da sociedade ao criminoso alerta: "sempre que o ser humano é usado e sacrificado como um meio para os fins da sociedade, toda humanidade (Menschlichkeit) superior se entristece" (Nietzsche, 2008, [186], p. 248). Neste caso a humanidade não é a coletividade dos seres humanos, mas a qualidade de ser humano (cf. nota 130, p. 325). 
haver o absoluto, nem a síntese (Resende; Passetti, 1986). Dessa maneira, a Anarquia não contemporiza com religiões ou mesmo qualquer forma de ecumenismo. Entretanto, a relação razão-religião é atravessada pelo Iluminismo, e só encontra ultrapassagem quando o anarquista estanca os condutores de consciências, pois a consciência libertária é efeito de novas práticas horizontalizadas e, portanto, múltipla. É preciso, portanto, cuidado para não fazer do iluminismo uma premissa para uma igreja da razão libertária.

A conclusão parcial das análises de Proudhon, caminha para a substituição do Estado pela Sociedade, ou Anarquia. Estaria aqui o final da sequência da história da injustiça? Iniciada na Comunidade foi substituída pela Propriedade, em que aconteceu a inversão da exploração inicial (do forte pelo fraco devido às intempéries da natureza), provocando a exploração do fraco pelo forte, com o advento do direito fundado na coerção e na astúcia resultante da vitória da força vencedora sobre as demais, impondo-lhes deveres. A justiça, portanto, aguarda a dissolução da exploração e da dominação, ainda que o justo como absoluto também seja inimaginável. Em Proudhon, reaparece a emergência do contrato na militância anarquista. Ele é anterior, um obstáculo ao Estado e à propriedade. Não é o fundador a-histórico do Estado como persegue a filosofia jurídico-política. É um contrato entre dois ou mais de dois, revertendo a sua suposta universidade e reafirmando sua historicidade. Funciona no âmbito de uma heterotopia de percurso (Passetti, 2003), em que se o destino almejado é o fim da propriedade e do Estado, o que interessa é o atual momento da configuração das injustiças. Trata-se de encontrar um direito antissoberania, de um rompimento possível pelas práticas do militantismo, de um estilo de vida anarquista e anticapitalista que se expande e que depende das lutas. Se no século XIX dizia respeito à capacidade política da classe operária, hoje desafia o conjunto dos trabalhadores. O problema apresentado por Proudhon, neste caso, não se distancia das análises de Foucault, no que este pode ter de anarquista, principalmente no que tange às análises sobre resistências e heterotopias.

Todavia, a constatação crítica de Proudhon, resvala no universal, quando a Sociedade ou a Anarquia parecem ser o rumo final da sequência iniciada com a comunidade e os subsequentes equacionamentos da injustiça. Em Proudhon, assim como nos 
anarquistas o fim da exploração capitalista e da dominação pelo Estado, parecem dar fim às injustiças na Propriedade. A resposta menos apressada diria que a Anarquia é o equacionamento das injustiças herdadas e das atuais. Se não devemos tratar como equívoco a construção da série de Proudhon (ComunidadePropriedade-Anarquia/Sociedade) em relação às injustiças, devemos também considerar que este ponto de inflexão produzido por novas relações horizontais, federativas e de direito não situarão a questão da justiça exaurida; as injustiças que deixam de existir são as relativas à exploração e à dominação, porém, novas situações a respeito do injusto estarão dispostas para equacionamentos federativos e mutualistas (Proudhon, 2000).

Esta resposta proudhoniana pode ainda não ser convincente. A questão está em aceitar a Anarquia ou a Sociedade como etapa posterior. Se falarmos de Anarquia propriamente dita, o equacionamento anterior pode e deve escapar do universalismo. Mas se aceitarmos que a Sociedade sucede a Propriedade, o consolo utópico pode amenizar a intensidade das lutas nas realizações heterotópicas anarquistas e provocar refluxos. A crítica a este universal anarquista por Foucault, foi tratada por Nietzsche na orla do ressentimento, da inversão do legado aristocrático de comando, da falta de imaginação para inventar novas relações que evitassem o eterno retorno. Foi tratada também com rigor, antes de Nietzsche, por Max Stirner que situou a inversão de domínio do Estado pela Sociedade, como um discurso repleto de altruísmos, produzindo uma inversão formal que pouco ou nada garante a liberdade de cada um por cada um. E está presente também em Foucault, acrescentando a negatividade do poder. Mas Foucault deu pouca atenção para que em Proudhon não há supressão de relações de poder no terminal seguinte. Estas passam a ser de outra magnitude; se em Proudhon há um discurso antipoder ele o é histórico, assim como em Bakunin, e diz respeito às relações no capitalismo projetadas para qualquer Sociedade superior a ser constituída comandada pelo domínio do Estado como inversão de forças de ocupação (como, por exemplo, o proletariado organizado em partido condutor da planificação econômica e das consciências no socialismo). Não se trata de constatar em Foucault um discurso nada novo diante do que os anarquistas já tinham produzido. Foucault, aos seus propósitos, indica 
percursos próximos aos anarquistas, quando se volta para as resistências. Foucault e os anarquistas se tocam, se encontram. As análises de Foucault debruçam-se no presente, sem apego a uma utopia ou a um futuro almejado, sequer apresentando um cálculo probabilístico de encerramento de um acontecimento. E é aí, e por isso mesmo, que suas análises são imprescindíveis aos anarquistas. Não só porque os anarquistas não buscam uma teoria do poder, da revolução, ou do futuro. O resultado da análise serial de Proudhon é somente um efeito nos anarquismos, haja vista a predominância de Bakunin e do revolucionarismo desde os confrontos abertos com o Marx e seus correligionários, a disputa entre a teoria da revolução e do seu partido diante do anarcossindicalismo, dos efeitos da revolução russa e dos outros embates gerados pela predominância anarquista como na revolução espanhola. Foucault, como os anarquistas, está voltado para a luta no presente.

Foucault, curiosamente, esteve mais atento a Bakunin que a Proudhon, explicitamente em seus escritos sobre o universal anarquista; e muito mais próximo de Proudhon que de Bakunin, mas não dito e escrito, quanto às relações de poder, direito, ao que chama de heterotopia e às implicações de uma guerra permanente quanto às resistências. Nestes termos, pode-se dizer que se a utopia anarquista também "consola" e se aproxima da dos comunistas, assunto no qual Lenin foi exímio em seu $O$ Estado e a revolução (1974), a heterotopia anarquista é mais intensa na dinâmica do duelo e ainda conserva, hoje, a inventividade do militantismo nas resistências.

Tomemos uma discussão nada trivial nos anarquismos sobre individualismo e coletivismo (isso não é uma digressão!). A respeito da predominância de um sobre o outro, das táticas de cada posição, das ênfases necessárias, das construções de subjetividades até uma disputa inócua entre a mais verdadeira, porque necessária e suficiente, instala-se um gigantesco precipício, ou como alguns preferem, por acomodação, simplesmente um impasse. De seu lado, os defensores do individualismo, obviamente distanciados dos supostos liberais, afirmam que algo começa no indivíduo. Foucault (2004), ao situar a decisão ética de cada um, desconsiderando a ética como conduta individual diante da moral, o que seria simplesmente afirmar o social (ou o coletivo) como a priori, também deposita neste querer o impossível diante do possível, ou seja, as práticas enunciando o 
insuportável e a dissolução do sujeito. Os coletivistas, por sua vez, acreditam que o indivíduo se move pela possibilidade de coletivo ou social e que é em função de um novo coletivo ou de sua conservação que as condutas dos indivíduos são balizadas. No limite, tal discussão opõe Proudhon como individualista e Bakunin como coletivista e divide, antes de tudo, as práticas anarquistas. Sim, se é a revolta que move o humano diante da natureza dos animais como situa Bakunin, isso ocorre porque há um social, cultural, coletivo a ser desafiado, mas é também uma atitude do indivíduo que o move diante do instituído como coletivo. É um tanto de revolta como situou Foucault (2004a) em relação ao risco de morte. É o desafio heterotópico do anarquista na sociedade em que vive para que o evento revolucionário se houver, não reponha o aparelho de Estado vigente nem as práticas cotidianas governadas por relações de poder verticalizadas. Por essa via, nem Proudhon, nem Bakunin teriam o que discordar e muito menos Foucault. Há uma atitude radical que move cada um em direção a uma transformação nas relações de poder. E é impossível traçar uma fronteira entre individualismo e coletivismo nas práticas anarquistas. No limite, é apenas um pernicioso contraposicionamento interno que ao passar a ser uma dissidência, torna-se política e aí os anarquismos tendem a ser capturados ou devorados.

Para os anarquistas não se trata de tomar meramente o poder para distribuí-lo ao proletariado, o que seria, antes de qualquer coisa, objeto de certa seletividade por sujeitos superiores, a reiteração inconteste da intransigência de Nietzsche com os revolucionários anarquistas. As análises presenciais de Alexander Berkman (2007; 2017) durante a revolução russa mostram que as decisões de cúpula, a programação econômica, o fechamento da assembleia, a combinação da produção com concessões aos capitalistas europeus, as gestões individualistas nas fábricas, o domínio sobre a ração diária do trabalhador, a submissão dos sindicatos, e o extremismo em relação à usurpação da propriedade pelo Estado levou ao crescimento da burocracia, ao poder de polícia da Tcheka, ao Exército Vermelho, ao fim da revolução. Neste entremeio a parceria dos bolchevistas com os anarquistas, crentes em "todo poder aos soviets", e os socialistas revolucionários também chegou ao fim quando os anarquistas foram condenados como bandidos. Para os bolchevistas, os anarquistas eram os individualistas! 
Emma Goldman (2007), também presente na aurora da revolução, ou seja, no mesmo período de consolidação dos bolchevistas vivido por Berkman, até a instauração da NEP - Nova Política Econômica, em 1921, alertou para efeitos da colaboração anarquista com os bolchevistas, ressaltando que alguns anarquistas tem um preço sim, e que a ideia de coletivismo é sempre mais perigosa do que se supõe: requer práticas verticalizadas e seduz; traz os anarquistas para dentro do governo ou apoio (e, neste sentido, ela já se adiantava à colaboração dos anarquistas com o governo republicano durante a revolução espanhola). No caso dos primeiros anos da revolução russa, o contraposicionamento anarquista funcionou como um contrapoder que fortaleceu os bolchevistas. Assim sendo, a disputa entre individualismo e coletivismo se torna análoga aos episódios pós-revolucionários na Rússia que levou a uma contenda na qual uma força mais forte visou a hegemonia, a condução, o reconhecimento parcial do outro e sua subalternização, o que deve ser aceito ou não definido pelos superiores, seus direitos. A disputa entre individualismo e coletivismo, por sua vez, reproduz, mesmo que não intencionalmente o contraposicionamento anarquista na revolução russa e em parte na revolução espanhola. A oposição individualismo-coletivismo é nociva aos anarquismos.

Emma Goldman (2008) coloca um condimento suplementar na discussão. Para ela, é impossível constatar uma mudança que não tenha passado pelo indivíduo. Até mesmo Jesus e Lutero, compuseram minorias. Somente mais tarde, essas minorias de contrapoder se tornaram maioria. Neste ponto nodal está a discussão acerca das práticas anarquistas equidistantes de uma querela acirrada sobre individualismo e coletivismo. O surgimento da massa, no final do século XIX, os efeitos do massacre da Comuna de Paris em 1871, a disputa pela sua condução (com o proletariado e com o campesinato) por um partido ou de práticas anarcossindicalistas, ou ainda do anarcoterrorismo, deram novos contornos às disputas. A maioria, segundo Goldman, confia seu destino à minoria e forma uma massa compacta que solapa quaisquer minorias potentes. A maioria passou a desconhecer que é a minoria que detém a riqueza, e que é esta minoria que a conduz e que a ela se assujeita.

A massa é uma forma social e política do pastorado moderno, de indivíduos mortificados, segundo Foucault; a massa é uma maneira 
de se conduzir pela inércia e a covardia, enfatiza Goldman. Assim, o governo da maioria pela minoria se funda na opinião pública e no espetáculo, enquanto as demais minorias são silenciadas. Se a massa sofre, a admiração por ela redunda em um quanto de biopolítica, ou um tanto de revolução. Em ambos os casos, a massa está disponível a ser governada, pois é ela mesma a responsável e disposta a ser soldado, polícia, carcereiro e algoz, compor o exército de reserva de poder. É matéria viva para o Estado. A vida uniforme almejada pela massa é possível pelo extermínio de individualidades, originalidades e livres iniciativas, enfatiza Goldman. Nos termos de Foucault, encontra-se, aí desde o século XIX, a acomodação no assujeitamento - cujo limite do poder soberano no século XX situa o direito de quem deve viver e de quem deve morrer —, e também a reversão resistente pela unidade política dos ilegalismos populares.

É a maioria que fortalece o exército de reserva de poder, que crê no contrato, na falta de Estado, em compensações. Ela se move como o bom governo dos súditos entre os súditos por adesão e medo. A minoria potente que dela se desprende coloca em questionamento o Estado, o direito, a justiça e a propriedade. É desnecessário elencar as familiaridades analíticas de Goldman com Foucault desde Vigiar e punir, quando estão em jogo as resistências. Para Goldman, a maioria carece não de elogios - como os revolucionários comunistas a adornam com palavras de respeito ao seu sofrimento e promessas de superações -, mas de educação produzida na luta. Os comunistas, por sua vez, veem a educação como programa ideológico para a revolução e posterior subalternização à política do partido, depois de tomar o poder. Os democratas se refestelam na massa, para não falar dos fascistas e nazistas que nela pousam confortavelmente por um breve tempo, porque também ela assim o é e os amam. E o que dizer da racionalidade neoliberal que estratifica a população em minorias, as faz portadoras de direitos inacabados e as convertem em seguidoras constantes, participando do jogo político, compondo para atuar como maioria em ação? E como as massas convertidas em minorias apreciam as punições, as criminalizações de condutas, como fazem acontecer seus ressentimentos invertendo uma norma ou lei que era adversa em favorável e adversa aos novos inimigos!

Goldman considera que a massa, ou hoje em dia as minorias voltadas para a composição em maioria, dependem de minorias 
inteligentes que situem onde está a minoria que detém a materialidade da riqueza. Uma minoria que não quer ser seguida, porque toda minoria que deseja ser seguida apenas restaura o pastorado moderno, é uma condução que se dá pelo alto e depende das mais variadas formas de produzir o governo dos súditos pelos súditos. Em contrapartida produz um saber-poder sobre os controles que se firmam no Estado como procedentes das práticas de baixo, como um poder de polícia. Enfim, se o conceito de massa teve uma presença fundamental nas práticas revolucionárias e nas democráticas foi porque sua força de controle, seu subpoder foi necessário para que o sobrelucro capitalista (Foucault, 2005) e o sobrepoder socialista se consolidassem com maior ou menor longevidades. É pouco relevante continuar com o conceito de massa, mesmo porque a massa não é e nunca foi compacta e contínua (Canetti, 1995).

Nietzsche, em Humano Demasiado Humano II, O andarilho [292]:

Atualmente todos os poderes buscam explorar o medo do socialismo, a fim de se fortalecer. A longo prazo, no entanto, apenas a democracia tira vantagem disso: pois todos os partidos são agora obrigados a lisonjear "o povo" e lhe proporcionar facilidades e liberdades de todo tipo, com as quais, enfim, ele se torna onipotente. O povo se acha bem distante do socialismo enquanto doutrina da mudança na aquisição da propriedade: e, quando, graças às maiorias em seus parlamentos tiver em mãos o torniquete dos impostos, atacará a elite capitalista comercial e financeira com o imposto progressivo e, aos poucos, criará realmente uma classe média que estará em condições de esquecer o socialismo como doença esperada. - $\mathrm{O}$ resultado prático dessa democratização que se espraia será, inicialmente, uma liga europeia de nações, em que cada nação, delimitada segundo as conveniências geográficas, terá a posição e os direitos especiais de um cantão: já não serão muito consideradas as lembranças históricas das nações até então havidas, pois o senso de devoção para com elas será gradualmente, erradicado, sob o governo do princípio 
democrático, sequioso de novidades e experimentos (grifos do autor).

Se Nietzsche, em certa medida, mata a charada da estratégia democrática nos nossos dias, ao anular, intimidar, capturar ou confinar práticas revolucionárias ao ostracismo, entre Foucault e os anarquistas há muitos pontos em comum ainda a serem traçados, menos sobre o que um repete do outro noutras palavras ou no que esconde, tarefa do exercício acadêmico, para ir direto ao que soma e potencializa. No final da vida, no perturbador curso sobre o cinismo, mais uma vez a presença de Foucault foi salutar aos anarquismos, ao recuperar práticas livres e de antipoder próprias aos anarquistas a partir de sua reflexão acerca do militantismo.

\section{Militantismo}

Foucault (2011) vai direto ao anarquismo e à sua manifestação da verdade (p.162), ao escândalo da verdade. Ele se coloca distante das interpretações acerca da descontinuidade entre o cinismo antigo e o moderno que os reconhecem aparentados e violentamente conflitantes, reduzindo-o ao individualismo, mas não atentando para o principal, ou seja, o escândalo da verdade. O cinismo não comporta a distinção entre o individualismo, o social, o cultural e o político. Segundo Foucault, entre estes opostos traçados pelos intérpretes do cinismo há uma transição na qual tanto o cristianismo europeu a ele se vincula pela introdução de práticas e instituições do ascetismo ${ }^{4}$, como as práticas revolucionárias do século XIX e a arte e a literatura modernas.

4 "A opção de vida como escândalo da verdade, o despojamento da vida como maneira de constituir, no próprio corpo, o teatro visível da verdade parecem ter sido, ao longo de toda história do cristianismo, não apenas um tema, mas uma prática particularmente viva, intensa, forte, em todos os esforços de reforma que se opuseram à Igreja, a suas instituições, a seu enriquecimento, 
Nesta segunda hora da aula de 29 de fevereiro de 1984, ele propõe um "passeio, um excurso, uma errância" (p. 155), ensaiando sugestões acerca de histórias a serem feitas a partir do cinismo. No caso das práticas revolucionárias do século XIX situa estes projetos políticos também como forma de vida, de militantismo: o das sociedades secretas (contra o visível e pautada em "princípio ou objetivo milenarista"); "a da organização visível, reconhecida, instituída, que procura impor seus objetivos e sua dinâmica no campo social e político, (...) se fazendo reconhecer em organizações sindicais ou partidos políticos com função revolucionária" (p.161), mas, também, o militantismo do "testemunho pela vida, na forma de um estilo de existência", uma ruptura com "as convenções, os hábitos, os valores da sociedade" (Idem, p. 161).

Imagina-se bem o que seria esta análise, importante de se fazer, do estilo de vida nos movimentos revolucionários europeus, mas, que eu saiba, isso nunca foi feito: como a ideia de uma cinismo da vida revolucionária como escândalo de uma verdade inaceitável se opôs à definição de uma conformidade de existência como condição para o militantismo em partidos que se dizem revolucionários. Seria outro objeto de estudo (Foucault, 2001: p.162).

\begin{abstract}
Abre-se a partir daí, segundo Foucault, a possibilidade para uma mirada ao cinismo desde Dostoiévski e o niilismo russo, aos anarquismos europeu e americano (tomo a licença de compreender os anarquismos das três Américas) e o terrorismo.

Quanto ao anarquismo, suas histórias de estilos de vida e estética da existência estão em arquivos vivos distribuídos pelo planeta, incursões históricas sobre práticas de educação, cultura libertária, liberação de costumes, ação direta, associações, centros de
\end{abstract}

\footnotetext{
a seu relaxamento de costumes. Houve todo um cinismo cristão, um cinismo anti-institucional, um cinismo que eu diria antieclesiástico, cujas formas e vestígios ainda vivos eram sensíveis à reforma, durante a Reforma, dentro da própria reforma protestante, ou mesmo da contrarreforma católica. Toda essa longa história do cinismo cristão poderia ser feita.” (Foucault, 2011, p. 160).
} 
cultura enfim, o infindável leque de práticas de rupturas e afirmações de hábitos, valores e novas convenções pelas práticas libertárias. A sugestão de Foucault reacende a chama da longevidade de práticas libertárias, agora vistas a partir de outra perspectiva histórica que não fere, mas potencializa, a inventiva história do anarquismo traçada por Max Nettlau (2008). Endereça-nos à reversão do eterno retorno e instiga à afirmação da vida outra libertária, livre da condução superior de herança aristocrática que contaminou o movimento revolucionário desde o século XIX pela direção do partido, assim como colabora para implodir a insistência universalista anarquista, trazendo para o presente a importância da luta, das heterotopias, enfim, um basta às pacificações neoliberais com suas práticas de minorias identitárias e criminalizadoras. E dentre as tantas outras possíveis brechas, propiciar afirmar que a prática pela tática black bloc é confirmação da vida, contra o que aí está, e que é o escândalo da vida. Assim, é simples compreender, segundo Foucault, que "neste Ocidente que inventou tantas verdades diversas e moldou artes de existência tão múltiplas, o cinismo não para de lembrar o seguinte: que muito pouca verdade é indispensável para quem quer viver verdadeiramente e que muito pouca vida é necessária quando se é verdadeiramente apegado à verdade" (Idem, p. 166).

Estamos no âmbito da reversão do ressentimento, para o qual as práticas anarquistas são decisivas. A potência das minorias absorvidas pela racionalidade neoliberal em direitos inacabados e seus portadores, restaurando a elite e produzindo outras que lhes são secundárias (justamente aquelas compostas por lideranças de movimentos de minorias voltados para se acomodar no governo de maioria), produz mais ressentimentos por meio de normas e leis criminalizadoras, e acolhidas em pacificações. Conduz comportamentos voltados para uma governança pela qual se pretende dissolver definitivamente a relação governantes-governados por meio da propagação de práticas democráticas (práticas de liberdade neoliberal), dinamizando o capital humano (os empreendedores de si) e situando-o em um novo assujeitamento, tanto pelas suas práticas de cidadão-polícia, zelando pela ordem e estabilidade na suas zonas de habitação ou comunidade, tornando-se um pastor de si e dos outros, como conformando-se como sujeito resiliente (aquele ou aquela capaz de se adaptar às situações difíceis e retornar à sua original 
condição), que tende a se voltar contra qualquer prática libertária, vista como violenta, bárbara, vândala e contrária ao pluralismo democrático. É a nova subjetividade do trabalhador assujeitado fomentando a continuidade da utopia liberal e do capitalismo. Os anarquistas se voltam para uma subjetivação outra.

Enquanto as condições das práticas de liberdade neoliberais estimulam e conferem autoridade ao ativismo (político, social, cultural, artístico), as práticas anarquistas se voltam para o militantismo. Todavia, a surpresa atual é a que nos remete a outra transição que ocorre neste século XXI, principalmente após o movimento antiglobalização que emergiu na década final do século $\mathrm{XX}$, e que invadiu o militantismo libertário, justamente as práticas ativistas. São marchas, protestos, caminhadas e tantas outras possíveis nomeações voltadas para adequar reivindicações, produzir outras ou reiterar outputs em função de tomadas de decisões legítimas, que envolvem tanto o governo do Estado, quanto organizações nãogovernamentais, fundações, institutos, partidos minoritários, sindicatos, movimentos minoritários de defesa de direitos, de reforma de costumes, de restauração conservadora da ordem. O ativismo não pode ser definido como de esquerda ou de direita. Ele vive de sua ambiguidade, ele precisa destas duas forças e do que elas conseguirem agregar em torno de uma questão, de um tema.

$\mathrm{O}$ ativismo também produz sua transições, fazendo com que forças à esquerda caminhem cada vez mais para o centro em função de não ferir as praxes democráticas e não aparecerem como sombra da ameaça revolucionária do passado; fazem questão de ser consensuais com as instituições, alegam que suas intervenções visam melhorá-las, que estão ao lado do sofrimento das massas e de sua baixa consciência para melhorá-las. Às vezes, lá estão eles, no limite, a pronunciar palavras-chave mais contestadoras como póscapitalismo; outras vezes, capturando práticas libertárias em palavraschave como autogestão, ação direta e imediatas; palavras que também migram para o discurso de direita, fortalecendo a racionalidade neoliberal. Uma direita orgulhosa que não se acanha em sequestrar para si a designação libertária, sinônimo de anarquista. Se à esquerda é importante ter à sua mão marginalmente os anarquistas, à direita é imprescindível ter os fascistas. É justamente pelos extremos que a oposição direita-esquerda robustece o centro. 
Situação-típica 1: a esquerda toma a dianteira como força hegemônica na luta antifascista, que também é própria dos anarquistas, e em nome da democracia, reusa os anarquistas com base no diálogo; situação típica 2: os liberais e neoliberais somam-se à luta antifascista, na medida em que estes clamam pelo messias, fazem uso de violência, alteram a situação de segurança razoavelmente estável, pretendem obstaculizar o funcionamento parlamentar. $\mathrm{O}$ troca-troca entre as duas forças direita e esquerda, exige, durante ou depois, anular ou colocar no ostracismo as suas duas forças marginais de apoio, respectivamente os anarquistas e os fascistas. $\mathrm{Na}$ atualidade, com o crescimento dos governos autoritários constituídos por meio de eleições democráticas, impulsiona as mídias e certos analistas a restaurarem o conceito de populismo, sublinhando os seus efeitos perversos à direita e à esquerda. A luta antifascista, então, configurase como luta democrática legítima e que não arranha a continuidade da racionalidade neoliberal no capitalismo, que nunca se fez de rogado: para sua assiduidade, ainda que a democracia seja o melhor dos regimes, ele funciona bem com qualquer outro, seja o fascismo e o nazismo no passado ( e não é necessário sequer lembrar das ditaduras latino-americanas no século $\mathrm{XX}$ ) ou a ditadura do proletariado chinesa no presente.

O ativismo é um obstáculo ao militantismo por atrair a luta anarquista para seu interior. Mais do que isso, o ativismo já tinha se imiscuído nos anarquismos ao reiterar a oposição individualismocoletivismo, proporcionando a aparição dos coletivistas como força hegemônica de condução e suprimindo as relações de transição. $\mathrm{O}$ militantismo anarquista atravessa essa situação tendo claro como suas invenções de costumes, hábitos e convenções não cedem ao ativismo que contamina algumas forças libertárias. Isso não é uma prescrição, é apenas uma constatação. Afinal, a anarquia começa onde trabalhamos, nas nossas relações de amizade e amorosidades, de sexo, de associações, educação de crianças, estilo de vida heterotópico diante da realidade.

As práticas anarquistas na atualidade, enfim, estão em uma dinâmica radical e noutras não tão radicais. De um lado, está a tática black bloc que atrai para dentro de si outras militâncias e jovens em 
busca de algo para além do ativismo ${ }^{5}$, para quem sabe, formar um bloco negro como uma prática anarquista ou não (Marestoni, 2019). De outro lado, a transversalidade democrática pode pacificar as práticas anarquistas seja em direção a uma aproximação com o marxismo libertário, seja a um "diálogo" político na "conjuntura", seja lá o que for que capture as práticas anarquistas em pacificações. O militantismo como expansão da vida, nas reflexões e práticas de Ôsugi Sakae (Uehara, 2019), nas práticas libertárias de antipolítica (Augusto, 2013), atravessaram o século XX, invadiram o XXI e pelo menos entre nós foi situado, entre outros, por Jourdan $(2018)^{6}$.

Penso, enfim, que deveria também situar as ressonâncias do militantismo na arte e na literatura (esta ficará para outra ocasião). Foucault situa a questão para além da vida de artista como uma vida singular, mostrando que "a vida do artista, deve, na forma em que ela assume, constituir um testemunho do que é a arte em sua verdade" (Foucault, 2011, p. 164). Uma arte que não estabelece mais com o real uma relação em torno do ornamento e da imitação, "mas que é da ordem do desnudamento, do desmascaramento, da decapagem, da escavação, da redução violenta ao elementar da existência" (Idem, p. 165), definitivamente antiplatônica. Mas, também, antiaristotélica, diante da herança adquirida, estabelecendo contra os cânones "uma relação polêmica de redução, de recusa, de agressão". É para ferir! "Ao consenso da cultura se opõe a coragem da arte em sua verdade bárbara. A arte moderna é o cinismo na cultura, é o cinismo da cultura voltada contra ela mesma" (Ibidem, idem). Afinal, "o cinismo constitui um ponto de incompatibilidade entre o éthos próprio da arte moderna e o éthos próprio da prática política, mesmo sendo

5 Ver Observatório ecopolítica, n. 49-50, 51 e 52 sobre a configuração da direita internacional na atualidade, Disponível em: http://www.pucsp.br/ecopolitica/observatorioecopolitica/n49-50.html, http://www.pucsp.br/ecopolitica/observatorio-ecopolitica/n51.html e http://www.pucsp.br/ecopolitica/observatorio-ecopolitica/n52.html assim como a coleção Flecheira Libertária, dos anos 2013 em diante, situando as variadas práticas anarquistas na atualidade. Disponível em http://www.nu-sol.org/flecheira-libertaria/

6 Cito apenas três interessantes e inquietantes estudos, diretamente relacionados aos propósitos deste artigo, sabedor que outros tantos também expressam esses militantismos no presente, assim como produzem incômodos aos anarquismos hegemônicos. Não estou sendo justo ou injusto com ninguém, apenas coerente com o escândalo da verdade, e também estou suficientemente esclarecido que não cabe ao trabalho acadêmico aventurar-se pelo escândalo. 
revolucionária" (Idem, p. 166). Mas a arte moderna foi se transformando em arte contemporânea.

Todavia, voltando ao início deste artigo, pretendo trazer a presença do artista chinês Ai Weiwei para situar o efeito contemporâneo do ativismo na arte. Para os propósitos deste artigo, penso que olhar para a produção deste artista, que recentemente visitou o Brasil, não somente mostrando sua obra, mas aqui produzindo algumas novas, possa nos levar a compreender melhor a vida de artista, própria do ativismo diante até mesmo da vida do anarquista como obra de arte. Pode nos fornecer pistas sobre a arte contemporânea que reajusta a reversão proporcionada pela arte moderna e pretende ajustála aos cânones aristotélicos e pacificar o antiplatonismo.

O catálogo da exposição de Weiwei no Brasil foi preparado por Dantas (2018), apresenta o trajeto do artista, filho de um dissidente da revolução cultural chinesa de 1966 que o marcou profundamente em sua vida de artista. Para Dantas, curador da exposição, trazer Weiwei para a América Latina era fazer funcionar "a ideia de situar o mais vulnerável no centro da ação e assim empoderá-lo de modo a causar uma mudança fundamental na percepção" (Dantas 2018, p. 5). Suas palavras iniciais definem com clareza a importância do ativismo na arte. É preciso que o artista realize seus projetos conjuntos com artesãos de variados ofícios, atingindo uma obra que expresse a importância política do social. A arte, assim, também participa da convocação â participação no interior de uma governamentalidade planetária, em destaque para o empoderamento do vulnerável. É uma arte que produz uma situação de envolvimento com os problemas ecológicos, de minorias e de crítica aos governos, de refugiados e populações ribeirinhas para chamar atenção para cuidados a serem despendidos com eles. É uma arte que ajusta, contesta e no limite produz dissidência. No Brasil Weiwei dedicou-se a questões ecológicas, aproximações com artesãos em madeira e até mesmo com prisioneiras produzindo uma "teresa" com uniformes das encarceradas, com anuência das respectivas autoridades. Chamou, significativamente, sua atividade de "mutuofagia" (ele e seus parceiros), redesenhando coerentemente a antropofagia, acompanhando as leituras de artistas estrangeiros como Ekhout e Debret, porém abandonando a tela convencional para produzir um trabalho conjunto de objetos sob sua orientação e 
supervisão. Não se trata de avaliar a qualidade dos objetos, vídeos, filmes, breves registros gravados por iphone, performances, etc. deste artista consagrado, seja nas intervenções imediatas, na Bienal de Veneza, na Documenta, mas de situar sua arte-ativista coerente com a produção contemporânea na arte diante de problemas humanitários, em especial a questão dos refugiados. Nele, desaparece a entrada do espectador na obra, podendo alterá-la, pela ênfase na presença de parcerias vindas de ofícios tradicionais de reconhecido refinamento na execução, para a confecção da obra; há menos do indivíduo modificando um objeto e mais o espectador apreciando a produção conjunta do objeto; há o artista ativista preponderando sobre o artista perturbador que atrai o espectador para experimentações estranhas como Lygia Clark, Lygia Pape, Hélio Oiticica, Cildo Meirelles e outros) $)^{7}$. A obra de Weiwei apresenta, também, uma aproximação adequada com a presença do Museu do Amanhã, no Rio de Janeiro, em torno do desenvolvimento sustentável.

Em pouco tempo, depois de passar pelos Estados Unidos "fui embora porque os ativistas de nosso próprio grupo tinham sido presos sob a acusação de que eram espiões do Ocidente, o que não fazia o menor sentido" (Idem, p. 21) -, Weiwei retornou à China e se viu entre ser cooptado pelo governo ou ser dissidente. Já sabia que com a pintura não obteria sucesso e constatou que na defesa dos direitos humanos e da liberdade de expressão estariam seus dois pilares, ou ainda a partir de sua percepção de que as raízes se comunicam no interior da superfície, para provocar possibilidades de práticas de liberdade de inspiração liberal. Tudo começou a funcionar em 1999, quando foi apresentado por Uli Sigg, ex-embaixador da Suíça na China e reconhecido colecionador de arte chinesa, a Harald Szeeman que o convidou para a Bienal de Veneza. Estava construída uma comunicação entre "raízes". Já era conhecida sua entrevista de 1995 a Zhang Hui onde dizia que o artista devia desempenhar o papel de vírus. É curioso que o vírus é a imagem escolhida por Deleuze para deflagrar o que seriam as resistências na sociedade de controle de comunicação contínua. Entretanto, se em Deleuze encontra-se uma

7 Aqui, também são vários os estudos sobre as obras destes artistas que escapam do ativismo. Para uma introdução a essa possível ampla caracterização, ver Carneiro (2004). 
disposição em indicar o vírus como interceptador de controles, em Weiwei o vírus é a conduta do artista que busca aperfeiçoar as deficiências da programação, contestar a vigilância do mundo racional, interceptar continuidades totalitárias em função e uma democracia liberal fundada na liberdade de expressão. Então, em 2005, ao ser convidado pelo site chinês sina.com aprendeu rapidamente a mexer com computadores e a linguagem eletrônica. Começou a postar fotografias, chegando a 100 mil acessos em seu blog, até tê-lo censurado com o fim do tempo de certa liberdade de expressão na China; desde então seu nome é censurado na Internet chinesa. Disse o arquiteto Yung Ho Chang em um debate com o colecionador Uli Sigg: "se você realmente quer ter um impacto na China de hoje, precisa ser intelectual público, exatamente o que Ai Weiwei é. Isso significa que você tem que estar disposto a gastar muita energia e muito tempo fazendo justamente isso, lidando com a mídia, por exemplo, em vez de fazer seu próximo trabalho". Weiwei respondeu: "mas esse é exatamente o meu trabalho" (idem, p. 45).

Weiwei se tornará um renomado artista destes tempos, relacionando suas obras a Duchamp e ao "estilo de vida", à "escultura social" aos moldes de Joseph Beuys, ao minimalismo de Donald Judd e Carl Andre, mas dando-lhes uma atualidade voltada para o ativismo: "ser uma artista, não importa como seja visto, é se colocar em ação e ser visionário. É pensar sobre produzir um evento, e o evento para mim é em última instância histórico, com a intenção de deixar uma marca histórica" (Idem, p. 51). E ele deixa a sua para os historiadores da arte ampliarem seu repertório. Mesmo pretendendo se diferenciar, Ai Weiwei ainda está sob o signo da vida de artista. Depois de passar pelos EUA e voltar à China, vive neste momento na Alemanha. Sua preocupação principal é a de "provocar transformações [nas] comunidades" (Idem, p. 171) com as quais se relaciona. E ao se referir às mulheres, reitera o transcendental na vida de artista: "As mulheres são a estrutura de nosso mundo emocional e intelectual. Deus nos criou em duas metades e temos de nos unir à outra metade" (Idem, p. 125).

A racionalidade neoliberal provoca práticas de liberdades ativistas nas mais variadas manifestações do humano e estabelece regras de participação em uma sociedade convocada insistentemente a obter protagonismos, valorizando e empoderando o vulnerável. A repercussão imediata está na dissidência e sua resiliência como 
retorno à participação moderada. Funciona para levar adiante a utopia liberal e suas pacificações.

A vida como obra de arte, todavia, como na tática black bloc, desvia da dissidência e da convocação à participação, instaura o risco de morte, a confrontação aberta, a produção ético-estética de corpos em negro sem rostos à vista que dissolve qualquer uniforme de minoria como vestimenta. Explicita a violência legítima do Estado e de suas forças repressivas, o significado do patrimônio público como realização do domínio elitista e seletivo, avança sobre os prédios dos financistas e do ideal de consumo, dá passagem para contestações radicais sem comunicar raízes, introduzem o inédito, o surpreendente, diante do insuportável. O negror do black bloc (que dissolve pela ação direta a fictícia oposição individualismo e coletivismo), no futuro também, poderá adornar a história da arte. Mas, antes disso, mancha a assepsia social imaginada pela racionalidade neoliberal e a prescrição a condutas moderadas, aquelas que aproximam ao centro a direita e a esquerda. Se a tática black bloc for metamorfoseada em bloco negro isso fica para os historiadores adiante. O anarquista no interior das manifestações e na tática black bloc, pelo menos até o momento, permanece produzindo sua vida como obra de arte, uma vida em expansão.

\section{Referências}

AUGUSTO, Acácio (2013). Política e antipolítica: anarquia contemporânea, revolta e cultura libertária. Tese de Doutoramento: PUC-SP.

BAKUNIN, Mikhail (2000). Deus e o Estado. São Paulo: NuSol/Imaginário/SOMA.

BERKMAN, Alexander (2007). “A tragédia russa (uma revisão e uma perspectiva - ou panorama). Tradução de Beatriz Carneiro. Revista Verve. São Paulo: Nu-Sol, n.12, pp. 81-115. http://www.nusol.org/verve/pdf/Verve12.pdf 
BERKMAN, Alexander (2017) "A revolução russa e o partido comunista". Tradução de Beatriz Carneiro. Revista Verve. São Paulo: Nu-Sol, n.32, pp. 82-127. Disponível em: http://www.nu-sol.org/wpcontent/uploads/2017/11/verve32.pdf

CANETTI, Elias (1995). Massa e poder. Tradução Sérgio Tellaroli. São Paulo: Companhia das Letras.

CARNEIRO, Beatriz (2004). Relâmpagos com claror. Lygia Clark e Hélio Oiticica, vida como arte. São Paulo: Imaginário-Fapesp.

DANTAS, Marcello (org) (2018). Raiz Weiwei. São Paulo: Ubu Editora.

FOUCAULT, Michel (1996). A verdade e as formas jurídicas. Tradução de Roberto C. M. Machado e Eduardo Jardim. Rio de Janeiro: Nau.

FOUCAULT, Michel (2004) A hermenêutica do sujeito. Tradução de Marcio A. da Fonseca e Salma T. Muchail. São Paulo: Martins Fontes.

FOUCAULT, Michel $\left(2004^{a}\right)$. "É inútil revoltar-se?" in Manoel B. da Motta; Michel Foucault. Ética, sexualidade, política. Coleção ditos e escritos, v. V. Tradução de Elisa Monteiro e Inês A. D. Barbosa. Editora: Forense Universitária. Rio de Janeiro, p. $77-81$.

FOUCAULT, Michel (2011). A coragem da verdade. Tradução de Eduardo Brandão. São Paulo: WFMartins.

GOLDMAN, Emma (2007). "Minha outra desilusão na Rússia". Tradução de Annamaria Salles. Revista Verve. São Paulo: Nu-Sol, n.11, pp.109-122. Disponível em: http://www.nusol.org/verve/pdf/Verve11.pdf

GOLDMAN, Emma (2008) . "Minorias versus maioria". Tradução de Eliane Knorr. Revista Verve. São Paulo: Nu-Sol, n.13, pp.123-133. Disponível em: http://www.nu-sol.org/wpcontent/uploads/2018/02/verve13.pdf

JOURDAN, Camila (2018). 2013. Memórias e resistências. Rio de Janeiro: Circuito. 
LENIN, Vladimir I. (1979). O Estado e a revolução. Tradução de Aristide Lobo. São Paulo: Hucitec.

NETTLAU, Max (2008). A história da anarquia: das origens ao anarco-comunismo. São Paulo: Hedra.

NIETZSCHE, Friedrich (1998). Genealogia da moral. Tradução de Paulo César de Souza. São Paulo: Companhia das Letras.

NIETZSCHE, Friedrich (2008). Humano, demasiado humano II. Tradução de Paulo César de Souza. São Paulo: Companhia das Letras.

MARESTONI, Matheus D.L. (2019) No fogo de 2013: ação direta anarquista, autonomismo e a democracia contemporânea. Dissertação de mestrado, PEPG-Ciências Sociais, PUC-SP.

PASSETTI, Edson (2003). "Vivendo e revirando-se. Heterotopias libertárias na sociedade de controle". Revista Verve São Paulo: NuSol., n. 4, pp. 32-55. Disponível em http://www.nu-sol.org/wpcontent/uploads/2017/11/verve3.pdf

STIRNER, Max (2004). O único e a sua propriedade. Tradução de João Barrento. Lisboa: Antígona.

PROUDHON, Pierre-Joseph (2004). Do Principio Federativo. Tradução de Francisco Trindade. São Paulo: Nu-Sol; Imaginário.

RESENDE, Paulo-Edgar A.; PASSETTI, Edson (1986). Proudhon. Coleção Grandes Cientista Sociais. Tradução Célia Gambini e Eunice Ornelas Setti. São Paulo: Ática.

UEHARA, Luíza (2019). Um anarquismo menor: práticas libertárias no Japão Imperial. Tese de Doutoramento: PUC-SP.

RECEBIDO EM: 15/06/2019

APROVADO EM: 18/06/2019 